\title{
KEBIJAKAN PENEGAKAN HUKUM TERHADAP TINDAK PIDANA TERORISME YANG DILAKUKAN KELOMPOK RADIKAL
}

\author{
Yasir Ahmadi \\ Kepolisian Sektor Medan Labuhan Utara \\ E-mail: yasirahmadi.ptik59@gmail.com
}

\begin{abstract}
Terrorism criminal has been thriven in Indonesia which can be threatened security in national or international scale. Because of that, Densus 88 AT Polri is given authority to take under control it. Law enforcemet of terrorism criminal needs to be solved integrally, planned and sustainable which is not only approached by penal solving but also solved by punishment the criminal. People should be realized that terrorism is threating thw wholeness and unity of Indonesa. The role of religion leader or society could actively play to enhance conscious and knowledge about nationality, so it can always responsive and alert to the movement of radical groups that developed in the area around.
\end{abstract}

\section{Kata Kunci: Kebijakan, Terorisme, Kelompok Radikal}

\section{A. Latar Belakang}

Menyikapi berbagai peristiwa serangan terorisme yang menyebabkan kekhawatiran di kalangan masyarakat Indonesia, maka pemerintah telah mengambil langkah-langkah strategis dalam menanggulangi tindak pidana terorisme, antara lain dengan dikeluarkannya Peraturan Pemerintah Pengganti Undang-undang Nomor 1 Tahun 2002 tentang Pemberantasan Tindak Pidana Terorisme (Perpu No. 1 Tahun 2002), dan setahun kemudian Perpu No. 1 Tahun 2002 ini disahkan menjadi undang-undang melalui Undang-undang Nomor 15 Tahun 2003 tentang Penetapan Peraturan Pemerintah Pengganti Undang-undang Nomor 1 Tahun 2002 tentang Pemberantasan Tindak Pidana Terorisme Menjadi Undang-undang (UU No. 15 Tahun 2003).

Dikeluarkannya undang-undang tersebut merupakan salah satu wujud nyata langkah pemerintah dalam upaya penanggulangan tindak pidana terorisme di Indonesia. Pemerintah menganggap perlu adanya peraturan khusus yang mengkriminalisasi kejahatan terorisme, karena selama ini di Indonesia belum ada 
peraturan perundang-undangan yang mengatur tentang terorisme, sedangkan dampak dari kejahatan ini yang sangat luas terhadap stabilitas keamanan nasional, maupun internasional.

Penanggulangan tindak pidana terorisme tentunya tidak cukup hanya dengan mengeluarkan berbagai regulasi ataupun kebijakan yang terkait dengan upaya tersebut, tetapi hal penting lain yang perlu diperhatikan adalah terkait dengan institusi Kepolisian Negara Republik Indonesia (Polri), yang merupakan garda terdepan dalam pengungkapan berbagai aksi terorisme yang terjadi di Indonesia, karena Polri mempunyai salah satu fungsi pemerintahan negara di bidang pemeliharaan keamanan dan ketertiban masyarakat, penegakan hukum, perlindungan, pengayoman, dan pelayanan kepada masyarakat, yang bertujuan untuk mewujudkan keamanan dalam negeri yang meliputi terpeliharanya keamanan dan ketertiban masyarakat, tertib dan tegaknya hukum, terselenggaranya perlindungan, pengayoman, dan pelayanan kepada masyarakat, serta terbinanya ketenteraman masyarakat dengan menjunjung tinggi hak asasi manusia.

Berdasarkan Keputusan Kapolri Nomor Polisi: Kep/30/VI/2003, tanggal 30 Juni 2003 tentang Organisasi dan Tata Kerja Satuan-satuan Organisasi pada Tingkat Markas Besar Kepolisian Negara Republik Indonesia, yang selanjutnya telah dirubah melalui Peraturan Kapolri Nomor 21 Tahun 2010 tentang Susunan Organisasi dan Tata Kerja Satuan Organisasi pada Tingkat Markas Besar Kepolisian Negara Republik Indonesia, maka kewenangan untuk mengungkap tindak pidana terorisme berada pada satuan Detasemen Khusus 88 Anti Teror (Densus 88 AT Polri).

Setelah Detasemen Khusus 88 Anti Teror Kepolisian Negara Republik Indonesia (selanjutnya disingkat Densus 88 AT Polri) terbentuk, maka makin banyak tindak pidana terorisme yang terungkap, dan gembong teroris juga banyak yang ditangkap serta telah dijatuhi pidana oleh pengadilan, tetapi upaya mengatasi berbagai aksi tindak pidana terorisme ini seolah-olah tidak dapat berhenti, karena sampai saat ini masih banyak peristiwa-peristiwa terorisme yang terjadi. Sehubungan hal ini, maka perlu kiranya dilakukan penelitian yang bertujuan 
untuk mengetahui kebijakan penegakan hukum terhadap tindak pidana terorisme yang dilakukan kelompok radikal di Indonesia.

\section{B. Metode Penelitian}

Penelitian ini merupakan penelitian yuridis normatif dengan pendekatan kasus. Sifat penelitiannya adalah deskriptif, dan berhubung merupakan penelitian yuridis normatif, maka data yang dianalisis adalah data sekunder, yang terdiri dari bahan hukum primer, bahan hukum sekunder dan bahan hukum tersier. Analisis terhadap data yang terkumpul dilakukan dengan teknik analisis kualitatif.

\section{Hasil Penelitian dan Pembahasan}

\section{Konsepsi penegakan hukum pidana}

Sistem peradilan pidana adalah sistem dalam suatu masyarakat untuk menanggulangi masalah kejahatan. Sistem ini dianggap berhasil apabila sebagian dari pelaporan maupun keluhan masyarakat yang menjadi korban kejahatan dapat diselesaikan dengan diajukannya pelaku ke sidang pengadilan dan diputuskan bersalah, serta mendapat sanksi pidana (Nuraeny 2011: 84). sedangkan menurut Mardjono Reksodiputro (1994: 140), dikatakan bahwa:

Cakupan tugas dari sistem peradilan pidana memang luas karena di dalamnya termasuk: (a) mencegah masyarakat menjadi korban kejahatan; (b) menyelesaikan kejahatan yang terjadi sehingga masyarakat puas bahwa keadilan telah ditegakkan dan yang bersalah dipidana; serta (c) berusaha agar mereka yang pernah melakukan kejahatan tidak mengulangi lagi perbuatannya.

Usaha tersebut dapat terwujud apabila penegakan hukum pidana dapat bekerja dengan baik, selaras dan berwibawa, terutama jika aparat penegakan hukum (polisi, jaksa, hakim dan petugas lembaga pemasyarakatan) dapat melaksanakan tugasnya sesuai dengan tanggung jawab yang diamanatkan oleh undang-undang. Keempat badan/institusi tersebut harus dapat bekerja sesuai dengan sistem managemen peradilan pidana yang berlaku.

Penegakan hukum (law enforcement) diartikan sebagai gejala sosial (kemasyarakatan) yang merupakan bagian dari kebijakan hukum yang dapat 
dilakukan dengan cara formulasi, aplikasi/yudikasi dan eksekusi. Pada tataran formulasi dilaksanakan oleh badan pembuat undang-undang, tataran aplikasi dilaksanakan oleh aparat penegak hukum, serta pada tataran eksekusi yaitu tahap pelaksanaan hukum pidana yang dilaksanakan oleh aparat pelaksana pidana (Nuraeny 2011: 85).

Penggunaan hukum pidana dalam penanggulangan kejahatan, hanya bersifat menyembuhkan gejala (kurieren am symptom) dan bukan sebagai faktor yang menghilangkan sebab terjadinya kejahatan. Adanya sanksi pidana merupakan usaha untuk mengatasi gejala atau akibat dari penyakit dan bukan sebagai obat (remedium) untuk mengatasi sebab terjadinya penyakit (Arief 2005: 44).

Hukum pidana memiliki kemampuan yang terbatas dalam upaya penanggulangan kejahatan yang begitu beragam dan kompleks. Berkaitan dengan kelemahan penggunaan hukum pidana, maka Roeslan Saleh (1983: 34), menyatakan bahwa:

Keragu-raguan masyarakat terhadap hukum pidana semakin besar sehubungan dengan praktek penyelenggaraan hukum pidana yang terlalu normatif-sistematis. Adapun batas kemampuan hukum pidana sebagai sarana kebijakan kriminal dalam penanggulangan kejahatan adalah:

a. Sebab kejahatan yang demikian kompleks berada di luar jangkauan hukum pidana;

b. Hukum pidana hanya merupakan bagian kecil (sub-sistem) dari sarana kontrol sosial yang tidak mungkin mengatasi masalah kejahatan sebagai masalah kemanusiaan dan kemasyarakatan yang sangat kompleks (sebagai masalah sosio-psikologis, sosio-politik, sosio-ekonomi, sosio-kultural, dan sebagainya;

c. Penggunaan hukum pidana dalam menanggulangi kejahatan hanya merupakan "kurieren am symptom", oleh karena itu hukum pidana hanya merupakan pengobatan simptomatik, dan bukan pengobatan kausatif;

d. Sanksi hukum pidana merupakan "remedium" yang mengandung sifat kontradiktif/paradoksal dan mengandung unsur serta efek sampingan yang negatif;

e. Sistem pemidanaan bersifat fragmentair dan individual/personal, tidak bersifat struktural/fungsional;

f. Keterbatasan jenis sanksi pidana dan sistem perumusan sanksi pidana yang bersifat kaku dan imperatif; dan

g. Bekerjanya/berfungsinya hukum pidana memerlukan sarana pendukung yang lebih bervariasi dan lebih menuntut biaya tinggi. 
Berdasarkan teori yang dikemukakan Barda Nawawi Arief (2005: 78), dijelaskan bahwa:

Pencegahan dan penanggulangan kejahatan harus dilakukan dengan pendekatan integral; ada keseimbangan sarana penal dan non-penal. Dilihat dari sudut politik kriminal, kebijakan paling strategis adalah melalui sarana non-penal karena lebih bersifat preventif, dan karena kebijakan penal keterbatasan atau kelemahan, yaitu bersifat fragmentaris/ simplistis/tidak struktural fungsional; simptomatik/tidak kausatif/tidak eliminatif; individualistik/offender-oriented/tidak victim oriented; lebih bersifat represif/tidak preventif; harus didukung oleh infrastruktur dengan biaya tinggi.

Pendekatan dengan sarana non-penal mencakup area pencegahan kejahatan (crime prevention) yang sangat luas. Pencegahan kejahatan pada dasarnya merupakan tujuan utama dari kebijakan kriminal. Pernyataan yang sering diungkapkan dalam kongres PBB mengenai "the prevention of crime and the treatment of offenders", yaitu:

a. Pencegahan kejahatan dan peradilan pidana janganlah diperlakukan/dilihat sebagai problem yang terpisah dan ditangani dengan metode yang simplistik dan fragmentair, tetapi seyogyanya dilihat sebagai masalah yang lebih kompleks dan ditangani dengan kebijakan/tindakan yang luas dan menyeluruh;

b. Pencegahan kejahatan harus didasarkan pada penghapusan sebab dan kondisi yang menyebabkan timbulnya kejahatan. Upaya penghapusan sebab dan kondisi yang demikian harus merupakan "strategi pokok/mendasar dalam upaya pencegahan kejahatan (the basic crime prevention strategy)"; dan

c. Penyebab utama dari kejahatan di banyak negara ialah ketimpangan sosial, diskriminasi rasial dan diskriminasi nasional, standar hidup yang rendah, pengangguran dan hubungannya dengan pembangunan ekonomi, sistem politik, nilai-nilai sosio kultural dan perubahan masyarakat, juga dalam hubungannya dengan tata ekonomi dunia/internasional baru.

Berdasarkan pernyataan dalam kongres PBB di atas, terlihat bahwa kebijakan penanggulangan kejahatan tidak hanya akan menyembuhkan atau membina para terpidana (penjahat) saja, tetapi penanggulangan kejahatan 
dilakukan juga dengan upaya penyembuhan masyarakat, yaitu dengan menghapuskan sebab, maupun kondisi yang menyebabkan terjadinya kejahatan.

Kejahatan bukan merupakan peristiwa herediter (bawaan sejak lahir atau warisan) juga bukan merupakan warisan biologis. Tingkah laku kriminal dapat dilakukan oleh siapapun juga, baik wanita maupun pria, dapat berlangsung pada usia anak, dewasa maupun lanjut usia. Tindak kejahatan dapat dilakukan secara sadar, dipikirkan, direncanakan ataupun diarahkan pada satu maksud tertentu secara sadar dan benar, tetapi dapat juga dilakukan secara setengah sadar, misalnya didorong oleh implus-implus yang hebat, didera oleh dorongandorongan paksaan yang sangat kuat (kompulsi-kompulsi) dan oleh obsesi-obsesi, misalnya karena terpaksa untuk mempertahankan hidupnya, seseorang harus melawan dan terpaksa membalas, menyerang sehingga terjadi peristiwa pembunuhan (Kartono 2003: 121).

W.A. Bonger sebagaimana dikutip Soerjono Soekanto (1985: 1), mendefenisikan bahwa: "kejahatan sebagai perbuatan anti sosial yang secara sadar mendapat reaksi dari negara berupa pemberian derita dan kemudian sebagai reaksi terhadap rumusan hukum (legal definition) mengenai kejahatan”. Paul Mudikdo Mulyono dalam Chainur Arrasjid (1999: 27), menyatakan bahwa: "kejahatan adalah perbuatan manusia yang merupakan pelanggaran norma yang dirasa merugikan, menjengkelkan, sehingga tidak boleh dibiarkan". Van Bammelen sebagaimana dikutip B. Simanjuntak (1997: 48), mengatakan bahwa: "kejahatan adalah tiap kelakukan yang bersifat tidak susila dan merugikan yang menimbulkan begitu banyak ketidaktenangan dalam suatu masyarakat tertentu".

Dalam perspektif ilmu kriminologi dipahami bahwa untuk penanggulangan tindak kejahatan (pidana) berarti harus dicari terlebih dahulu sebabnya seseorang melakukan tindak kejahatan. Ada banyak teori kejahatan yang menjelaskan sebab-sebab orang melakukan kejahatan. Salah satu teori yang perlu diperhatikan adalah "delinquent subculture" yang dikemukakan Albert K. Cohen (1955), sebagaimana dikutip Frans H. Winarta (www.sinarharapan.co.id., diakses pada tanggal 20 Januari 2015) yang mengatakan bahwa: 
Munculnya penyimpangan perilaku diawali frustrasi status yang mengarah pada deviant subculture, karena pelaku tidak mampu memenuhi standar yang telah ditetapkan kebudayaan dominan. Dengan demikian menurut Cohen bahwa faktor-faktor perbedaan nilai dan norma antara kelas atas, kelas menengah dan kelas bawah yang mendorong orang melakukan tindak pidana.

Menurut Soerjono Soekanto (2004: 5), mengatakan bahwa: "inti dan arti penegakan hukum terletak pada kegiatan menyerasikan hubungan nilai-nilai yang terjabarkan di dalam kaidah-kaidah yang mantap dan mengejewantah dan sikap tindak sebagai rangkaian penjabaran nilai tahap akhir, untuk menciptakan, memelihara dan mempertahankan kedamaian pergaulan hidup". Lebih lanjut Soerjono Soekanto (2004: 5), menyatakan bahwa masalah pokok penegakan hukum sebenarnya terletak pada faktor-faktor yang mungkin mempengaruhinya, yaitu:

a. Faktor undang-undang

Undang-undang (dalam arti materiil) yaitu peraturan tertulis yang berlaku umum dan dibuat oleh penguasa pusat maupun daerah. Faktor yang dapat mempengaruhi penegakan hukum dari sisi undangundang antara lain:

1) tidak diikutinya dengan benar asas-asas berlakunya undangundang yang bersangkutan;

2) belum adanya peraturan pelaksanaan yang sangat dibutuhkan untuk menerapkan undang-undang yang bersangkutan; dan

3) ketidakjelasan arti kata-kata dalam undang-undang yang mengakibatkan kesimpangsiuran dalam penafsiran serta penerapannya.

b. Faktor penegak hukum

Penegak hukum mencakup mereka yang secara langsung dan secara tidak langsung berkecimpung di bidang penegakan hukum. Ada beberapa faktor yang menghambat pelaksanaan penegakan hukum pada unsur penegak hukum. Faktor-faktor tersebut dapat berasal dari diri penegak hukum itu sendiri ataupun dari lingkungan luar, antara lain:

1) keterbatasan kemampuan untuk menempatkan diri dalam peranan fihak lain dengan siapa dia berinteraksi;

2) tingkat aspirasi yang relatif belum tinggi;

3) kegairahan yang sangat terbatas untuk memikirkan masa depan, sehingga sulit sekali membuat suatu proyeksi;

4) belum adanya kemampuan untuk menunda pemuasan suatu kebutuhan tertentu, terutama kebutuhan materiel; dan

5) daya inovatif masih kurang yang merupakan pasangan konservatisme. 
c. Faktor sarana atau fasilitas

Sarana atau fasilitas yang dimaksud antara lain mencakup sumberdaya manusia yang berpendidikan dan terampil, organisasi yang baik, peralatan yang memadai, keuangan yang cukup dan lain-lain. Sarana atau fasilitas ini mempunyai peranan penting dalam proses penegakan hukum, karena tanpa adanya sarana atau fasilitas tersebut, penegak hukum tidak mungkin dapat menyerasikan peranan yang seharusnya dengan peranan yang senyatanya.

d. Faktor masyarakat

Penegakan hukum berasal dari masyarakat dan bertujuan untuk mencapai kedamaian dalam masyarakat. Oleh karena itu, dipandang dari sudut tertentu, masyarakat dapat mempengaruhi penegakan hukum. Kompetensi hukum itu tidak mungkin ada, apabila masyarakatnya:

1) tidak mengetahui atau tidak menyadari, bahwa hak-hak mereka telah dilanggar atau diganggu;

2) tidak mengetahui akan adanya upaya-upaya hukum untuk melindungi kepentingannya;

3) tidak berdaya untuk memanfaatkan upaya-upaya hukum karena faktor-faktor keuangan, psikis, sosial atau politik;

4) tidak mempunyai pengalaman menjadi anggota organisasi yang memperjuangkan kepentingan-kepentingannya;

5) mempunyai pengalaman-pengalaman yang kurang baik dalam proses interaksi dengan pelbagai unsur kalangan hukum formal.

e. Faktor kebudayaan

Kebudayaan (sistem) hukum pada dasarnya mencakup nilai-nilai yang mendasari hukum yang berlaku, nilai-nilai tersebut merupakan konsepsi-konsepsi abstrak mengenai apa yang dianggap baik (diikuti) dan apa yang dianggap buruk (dihindari).

Kelima faktor tersebut akan sangat memengaruhi apakah penegakan hukum akan berjalan lancar atau akan mengalami hambatan-hambatan tertentu. Akibat adanya berbagai faktor yang mengganggu, maka penegakan hukum sulit terwujud dalam bentuknya yang total.

Penegakan hukum secara penuh (full enforcement) merupakan harapan yang tidak realistis (non a realistic expectation), karena terdapat kendala-kendala dalam pelaksanaannya, seperti karena keterbatasan waktu, personil, peralatan maupun sarana prasarana, sehingga mengharuskan adanya diskresi. Dengan demikian, yang tersisa hanyalah apa yang disebut dengan actual enforcement (penegakan hukum yang senyatanya) yaitu sebagai hasil dari total enforcement dikurangi area of no enforcement dikurangi lagi dengan adanya diskresi. 
Kelima faktor sebagaimana tersebut di atas, saling berkaitan dengan eratnya, karena merupakan esensi dari penegakkan hukum, juga merupakan tolak ukur dari efektivitas penegakkan hukum, tetapi dari semua faktor tersebut, maka faktor penegak hukum menempati titik sentral. Hal itu dikarenakan undangundang disusun oleh penegak hukum, penerapannya dilaksanakan oleh penegak hukum dan penegak hukum dianggap sebagai golongan panutan hukum oleh masyarakat luas (Soerjono Soekanto 2004: 69).

Dalam banyak hal ada kekeliruan pandangan mengenai lingkup aparat penegak hukum. Secara kelembagaan aparat penegak hukum tidak hanya polisi, jaksa dan hakim, melainkan termasuk juga berbagai badan pemerintah seperti pemasyarakatan, bea cukai, keimigrasian. Badan-badan ini selain menjalankan fungsi pelayanan, juga penegakan hukum. Tidaklah tepat kalau penegakan hukum hanya dibatasi pada lembaga yang melakukan tindakan represif pada saat terjadi pelanggaran hukum. Semestinya dalam penegakan hukum lazimnya menjelma dalam bentuk pelayanan hukum (Sho'an 2004: 13).

Penegakan hukum bukanlah semata-mata pelaksanaan perundangundangan, walaupun dalam kenyataan di Indonesia kecenderungannya adalah demikian, sehingga pengertian law enforcement begitu populer. Selain itu, ada kecenderungan yang kuat untuk mengartikan penegakan hukum sebagai pelaksanaan keputusan-keputusan hakim. Sudikno Mertokusumo (1988: 134-135), mengatakan bahwa masyarakat mengharapkan manfaat dalam pelaksanaan atau penegakan hukum, karena hukum adalah untuk manusia, maka pelaksanaan hukum atau penegakan hukum harus dapat memberikan manfaat atau kegunaan bagi masyarakat.

Hukum tidak mungkin akan tegak, jika hukum itu sendiri atau belum mencerminkan perasaan atau nilai-nilai keadilan yang hidup dalam masyarakatnya. Hukum tidak mungkin menjamin keadilan jika materinya sebagian besar merupakan warisan masa lalu atau yang lahir dan diwujudkan dalam bentuk peraturan perundang-undangan karena didasarkan pada kepentingan kelompok tertentu atau karena desakan pihak luar/asing yang sama sekali tidak mencerminkan nilai keadilan yang hidup dan berkembang dalam masyarakat. 
Dalam suatu pendapat menurut Wolf Middendorf sebagaimana dikutip Barda Nawawi Arif (2000: 83), dikatakan bahwa:

Penegakan hukum akan berjalan efektif apabila dipenuhi tiga faktor yang saling berkaitan yaitu: (a) adanya undang-undang yang baik (good legislation); (b) pelaksanaan yang cepat dan pasti (quick and certain enforcement); dan (c) pemidanaan yang layak atau sekedarnya dan seragam (moderate and uniform sentencing). Penegakan hukum dinilai berjalan efektif apabila dipenuhi tiga faktor yang saling berkaitan yaitu: undang-undang yang baik, pelaksanaan yang cepat dan pasti, serta penjatuhan hukum yang layak sesuai tingkat kesalahan pelaku tindak pidana.

Penegakan hukum dalam arti sempit adalah pemberian sanksi (pidana) oleh aparat penegak hukum pada setiap pelaku tindak pidana, sedangkan penegakan hukum dalam arti luas merupakan perhatian dan penggarapan perbuatan-perbuatan yang melawan hukum yang sungguh-sungguh terjadi (onrecht in $a d u$ ), maupun perbuatan melawan hukum yang mungkin akan terjadi (onrecht in potentie). Dengan demikian, penegakan hukum merupakan suatu proses untuk mewujudkan keinginan-keinginan hukum menjadi kenyataan dan keinginan-keinginan hukum yang dimaksud tidak lain adalah pikiran-pikiran badan pembuat undang-undang yang dirumuskan dalam peraturan-peraturan hukum itu. Secara lebih sistematis, menurut Barda Nawawi Arief (1998: 136), dikatakan bahwa:

Kebijakan penegakan hukum merupakan serangkaian proses yang terdiri dari 3 (tiga) tahap kebijakan yaitu: tahap kebijakan legislatif/formulatif, yudikatif/ aplikatif dan eksekutif/administratif. Dari ketiga tahap kebijakan penegakan hukum terkandung kekuasaan/kewenangan yaitu kekuasaan legislatif/formulatif untuk menetapkan ataupun merumuskan perbuatan apa yang dapat dihukum dan sanksi apa yang dapat dikenakan, sedangkan kekuasaan yudikatif/aplikatif adalah untuk penerapan hukum dan kekuasaan eksekutif/administratif adalah dalam hal pelaksanaan hukum.

Satjipto Raharjo seperti dikutip Nyoman Serikat Putrajaya (2005: 23), mengatakan bahwa: "proses penegakan hukum itu menjangkau pula sampai pada tahapan pembuatan hukum/undang-undang dan perumusan pikiran pembuat undang-undang yang dituangkan dalam peraturan perundang-undangan akan turut menentukan bagaimana penegakan hukum itu nanti dijalankan”. Barda Nawawi 
Arief (2002:73)., selanjutnya mengatakan bahwa: "kebijakan atau upaya penanggulangan kejahatan (criminal policy) pada hakekatnya merupakan bagian integral dari upaya perlindungan masyarakat (social defence) dan upaya mencapai kesejahteraan masyarakat (social welfare)".

\section{Kebijakan pidana penanggulangan tindak pidana terorisme}

Usaha pembaharuan terhadap Undang-undang Nomor 15 Tahun 2003 tentang Tindak Pidana Terorisme, juga terus dilakukan oleh pemerintah dan unsur-unsur terkait, hal ini nampak dalam konsiderans Rancangan UndangUndang tentang Perubahan Undang-undang Tindak Pidana Terorisme, menyebutkan bahwa untuk lebih menjamin kepastian hukum dan menghindari keragaman penafsiran dalam penegakan hukum serta memberikan perlindungan dan perlakuan secara adil kepada masyarakat dalam usaha mencegah dan memberantas terorisme, perlu diadakan perubahan atas Undang-undang Nomor 15 Tahun 2003 tentang Pemberantasan Tindak Pidana Terorisme

Rancangan Undang-Undang tentang Perubahan Undang-undang Tindak Pidana Terorisme, pada dasarnya memuat rancangan perubahan, sebagai berikut:

a. Menambah Pasal 9A tentang perdagangan bahan-bahan potensial yang digunakan sebagai bahan peledak atau membahayakan jiwa manusia dan lingkungan. Apabila bahan-bahan potensial tersebut terbukti digunakan dalam tindak pidana terorisme maka diberikan pemberantaran pidana;

b. Menambah Pasal 13A tentang orang yang mengetahui akan terjadinya tindak pidana terorisme tidak melaporkannya kepada pejabat yang berwenang. Apabila tindak pidana terorisme benar-benar terjadi maka diberikan pemberatan pidana;

c. Menambah Pasal 13B tentang:

1) larangan menjadi anggota organisasi yang bertujuan melakukan tindak pidana terorisme;

2) larangan mengenakan pakaian atau perlengkapan organisasi yang bertujuan melakukan tindak pidana terorisme di tempat umum;

3) meminta atau meminjam uang dan/atau barang dari organisasi yang bertujuan melakukan tindak pidana terorisme; 
d. Merubah Pasal 14 dengan menambah 1 (satu) ayat baru yakni ayat (2) tentang peringanan pidana terhadap pelaku apabila tindak pidana sebagaimana dimaksud pada ayat (1) tidak terjadi;

e. Mengubah Pasal 17 ayat (2) dengan rumusan baru yakni tindak pidana terorisme dilakukan oleh korporasi apabila tindak pidana tersebut dilakukan oleh orang-orang yang mempunyai wewenang mengambil keputusan, mewakili, dan/atau mengendalikan korporasi, baik berdasarkan hubungan kerja maupun hubungan lain, bertindak dalam lingkungan korporasi tersebut baik sendiri maupun bersama-sama.

f. Menyempurnakan perumusan Pasal 25 ayat (2) tentang jangka waktu penahanan, sebagai berikut:

1) untuk kepentingan penyidikan paling lama 120 (seratus dua puluh) hari;

2) untuk kepentingan penuntutan paling lama 60 (enam puluh) hari;

3) perpanjangan penahanan masing-masing terhadap proses penyidikan dan penuntutan dilakukan paling lama 30 (tiga puluh) hari dan dapat diperpanjang 1 (satu) kali untuk waktu paling lama 30 (tiga puluh) hari;

g. Mengubah Pasal 26 tentang cara memperoleh bukti permulaan yang cukup dan penetapan bahwa sudah dapat atau diperoleh bukti permulaan yang cukup;

h. Mengubah Pasal 27 dengan huruf d baru tentang laporan intelijen yang diperoleh selama penyidikan dan penuntutan setelah memenuhi ketentuan Pasal 26;

i. Mengubah perumusan Pasal 28 tentang jangka waktu penangkapan terhadap setiap orang yang diduga keras melakukan tindak pidana terorisme berdasarkan bukti permulaan yang cukup untuk paling lama 7 x 24 (tujuh kali dua puluh empat) jam;

j. Mengubah dan menambah Pasal 31 ayat (2) dengan 1 (satu) ayat baru yakni ayat (2a) tentang tindakan penyadapan hanya dapat dilakukan berdasarkan penetapan Hakim Pengadilan Negeri untuk tenggang waktu yang ditentukan dalam penetapan tersebut;

k. Mengubah ketentuan Pasal 33 tentang perlindungan negara terhadap saksi, penyidik, advokat, penuntut umum, dan hakim beserta keluarganya dari 
kemungkinan ancaman yang membahayakan diri, jiwa, dan/atau hartanya, baik sebelum, selama, maupun sesudah proses pemeriksaan perkara;

1. Menambah Pasal 34A tentang pemberian keterangan pada saat pemeriksaan di sidang pengadilan tanpa bertatap muka denga tersangka;

m. Menambah Ketentuan Peralihan (Bab VIIA, Pasal 43);

n. Menghapus Pasal 46;

o. Menghapus penjelasan umum angka 5

Memerhatikan isi Rancangan Undang-undang tentang Perubahan atas Undang-undang Tindak Pidana Terorisme, terlihat bahwa masalah pemidanaan, masih mempertahankan ancaman pidana minimal khusus terhadap tindak pidana terorisme, tetapi dalam tidak dibuatkan aturan/pedoman penerapannya. Masalah penahanan terhadap tersangka terorisme juga tidak ada perubahan, padahal masalah penahanan merupakan paling menentukan proses hukum tersangka terorisme, bahkan selama ini masyarakat hanya melihat hasilnya bahwa pihak kepolisian telah berhasil menangkap dan mengungkap jaringan terorisme dan membawanya kepengadilan, tetapi tidak melihat kesulitan-kesulitan yang dihadapi petugas-petugas di lapangan karena terbatasnya waktu penahanan.

Berdasarkan pengalaman empiris anggota Densus 88 AT Polri, ternyata penangkapan jaringan terorisme dengan cara biasa yang mengacu pada KUHAP akan mempersulit proses penangkapan selanjutnya. Hal ini dapat dibuktikan dengan jarak waktu penangkapan kelompok satu dengan kelompok lainnya memerlukan waktu 2 (dua) bulan atau lebih, dan waktu proses penangkapan selanjutnya memerlukan waktu yang lebih lama lagi, karena jaringan tersangka teroris juga mempelajaran pola penangkapan rekan-rekan mereka.

Semestinya dalam upaya pencegahan dan penanggulangan tindak pidana teorisme dengan sarana penal, maka fungsionalisasi/operasionalisasinya dilakukan melalui: (1) tahap formulasi (kebijakan legislatif); (2) tahap aplikasi (kebijakan yudikatif); dan (3) tahap eksekusi (kebijakan administratif). Tahap formulasi atau kebijakan legislatif merupakan tahap terpenting, yang merupakan proses pembuatan peraturan perundang-undangan yang dilakukan oleh pembuat undang- 
undang, sehingga setiap aturan hukum yang dibuat hendaknya dapat menjangkau setiap kebutuhan dan kejadian dalam masyarakat (Arief 2001:75).

Tahap kebijakan legislasi adalah tahap yang paling strategis, karena pada tahap ini akan dihasilkan suatu peraturan hukum yang akan menjadi pedoman pada tahap-tahap berikutnya dalam proses kebijakan hukum. Produk legislatif yang dinamakan undang-undang ini dalam tataran kebijakan hukum merupakan tataran formulasi, dan posisinya berada dalam tataran abstrak (berupa peraturan/ undang-undang), artinya undang-undang ini akan mempunyai makna, apabila di berlakukan dalam realitas. Oleh sebab itu, agar undang-undang dapat terealisasi dalam masyarakat, diperlukan badan-badan yang dapat melaksanakannya yang dalam ilmu hukum/ilmu politik dinamakan badan eksekutif, sedangkan badan yang bertugas menerapkan atau mengefektifkan peraturan perundang-undangan dinamakan badan yudisial/badan yudikatif yang mandiri dan netral, serta bebas dari campur tangan badan lainnya (Arief 2001: 94-95).

Kebijakan formulasi/legislatif juga berhubungan dengan masalah penitensier, yang merupakan bagian perpenting dari kebijakan pemidanaan (sentencing policy), yang menurut Herbert L. Parker (1968:13-15), merupakan salah satu masalah kontroversial dalam hukum pidana. Kebijakan legislasi sebagai salah satu bagian dari fungsionalisasi/operasionalisasi kebijakan hukum pidana dalam pencegahan dan penanggulangan tindak pidana sebenarnya juga tidak terlepas dari upaya memberikan perlindungan dan keadilan terhadap korban kejahatan.

Kebijakan legislasi merupakan tahap paling strategis dari upaya penanggulangan kejahatan dengan menggunakan sarana penal, dan disebut strategis, karena pada tahap inilah ditetapkan pedoman-pedoman bagi pelaksanaan tahap-tahap selanjutnya, yaitu tahap aplikasi dan eksekusi. Dengan kata lain, kesalahan dalam membuat suatu formulasi peraturan perundang-undangan maka akan berdampak negatif bagi operasionalisasi dari aplikasi dan eksekusi peraturan tersebut. Tahap formulasi juga disebut penegakan hukum in abstracto oleh badan legislatif sebagai lembaga yang mempunyai kewenangan untuk membuat kebijakan formulasi. 


\section{Penegakan hukum tindak pidana terorisme kelompok radikal}

Diawali dengan peristiwa Bom Bali pada tanggal 12 Oktober 2002, penanganan tindak pidana terorisme mulai dilaksanakan secara serius di Indonesia. Proses penanganan mulai dari penyelidikan, penyidikan, penuntutan dan proses peradilan merupakan tantangan yuridis bagi aparat penegak hukum, karena pada saat itu belum ada peraturan yang baku dan standard yang dapat digunakan untuk menangani perkara tindak pidana terorisme tersebut.

Mengantisipasi kekosongan hukum untuk menangani kasus terorisme tersebut Pemerintah Indonesia pada tanggal 28 Oktober 2002 atau 6 (enam) hari setelah peristiwa Bom Bali, mengeluarkan 2 (dua) peraturan pemerintah pengganti undang-undang, yaitu Peraturan Pemerintah Pengganti Undang-undang Nomor 1 Tahun 2002 tentang Pemberantasan Tindak Pidana Terorisme, kemudian disahkan menjadi undang-undang melalui Undang-undang Nomor 15 Tahun 2003 dan Peraturan Pemerintah Pengganti Undang-undang Nomor 2 Tahun 2002 tentang Pemberlakuan Peraturan Pemerintah Pengganti Undang-undang Nomor 1 Tahun 2002 pada Peristiwa Peledakan Bom Bali tanggal 12 Oktober 2002 (kemudian disahkan menjadi undang-undang melalui Undang-undang Nomor 16 Tahun 2003. Walaupun kedua peraturan pemerintah pengganti undang-undang ada, penanganan tindak pidana terorisme pada kasus Bom Bali tetap sangat merepotkan aparat kepolisian yang bertugas di lapangan.

Pada saat pengeboman di Bali tanggal 12 Oktober 2002, aparat Polri saat itu belum siap untuk menanggulanginya, baik dari kesiapan sumber daya manusia, sarana penunjang, pengetahuan dan pengalaman, maupun prosedur penanganannya. Akhirnya dengan modal dukungan internasional dan Pemerintah Indonesia, kemauan dan semangat yang sangat besar, ditambah dengan Keputusan Kapolri untuk membentuk Satuan Tugas Bom dan Kesepakatan Kerjasama dengan Polisi Federal Australia, maka kasus Bom Bali dapat diungkap dalam waktu yang relatif cepat dan dapat menangkap sebagian besar pelakunya.

Mengingat jaringan teroris yang berkembang di berbagai negara lain dan di Indonesia khususnya, maka semua institusi intelijen, serta instansi lain yang terkait harus disinergikan untuk memberantas tindak pidana terorisme. Demi 
tercapainya kesinergian kerja dimaksud, maka dipandang perlu mengambil langkah-langkah guna memantapkan hubungan dan mekanisme kerja antar institusi dalam bidang tugas intelijen. Hubungan mekanisme kerja itu dimulai dari tingkat perencanaan sampai pelaksanaan operasional. Mekanisme kerja di tingkat perencanaan dan pelaksanaan oprasional intelijen, sebenarnya dapat dilakukan dengan cara:

a. penggunaan teknologi mutakhir untuk melakukan surveillance dan intersepsi;

b. penyusupan ke dalam organisasi teroris;

c. pengembangan sistem deteksi dini ;

d. pertukaran informasi intelijen dengan negara lain;

e. pembangunan database terorisme ; dan

f. deteksi dini terhadap provokasi ke arah permusuhan bernuansa SARA dan kebencian terhadap kelompok, agama atau negara tertentu.

Badan Intelijen Negara sebagai lembaga pemerintah non departemen yang memiliki kompetensi paling utama, dipandang tepat untuk mengkoordinasikan perencanaan umum dan pelaksanaan operasional kegiatan intelijen kepada instansi-instansi lainnya, guna mendukung penyelenggaraan tugas pokok masingmasing, dan untuk melaksanakan tugas penyelidikan tindak pidana terorisme, maka Densus 88 AT Polri yang harus mengembangkan sendiri apa yang dibutuhkan dalam pelaksanaan tugas tersebut.

Produk bidang intelijen tentang kebenaran fakta akan melahirkan bukti permulaan yang menjadi dasar penyidikan. Kebenaran fakta ini memberikan justifikasi kepada penyidik terhadap langkah penangkapan dan penahanan. Selain itu, laporan intelijen sekaligus menjadi bahan klarifikasi untuk menghindari timbulnya kesewenang-wenangan dalam penangkapan dan meyakinkan tentang kebenaran objektif fakta yang ada sebagai bukti permulaan, tidak merupakan rekayasa yang dipaksakan untuk dapat memasuki proses penyidikan, karena berdasarkan Pasal 28 Perpu No. 1 Tahun 2002, ditentukan bahwa penyidik dapat melakukan penangkapan terhadap setiap orang yang diduga keras melakukan tindak pidana terorisme berdasarkan bukti permulaan. Lazimnya buktinya permulaan ini dapat diperoleh dari laporan intelijen. 
Terkait dengan investigasi tindak pidana terorisme, menurut Arsyad Mbai (2003: 17)., ada beberapa langkah yang perlu dilakukan, yaitu:

a. melakukan olah TKP secara profesional;

b. melakukan upaya paksa seperti penangkapan, penahanan, pemeriksaan sesuai ketentuan hukum dengan menghindari terjadinya pelanggaran hak asasi manusia, serta penyimpangan lainnya;

c. kerjasama internasional dalam penyidikan termasuk kerjasama penggunaan teknologi mutahir dalam penyidikan;

d. kerjasama internasional di bidang teknis seperti laboratorium, cyber forensic, communication forensic, surveillance, identifikasi dan dukungan teknis lainnya;

e. pelatihan penyidik di bidang investigasi;

f. latihan simulasi satuan-satuan anti-teror TNI dan Polri dalam penanganan terorisme;

g. memperbanyak dan mengintensifkan informan;

h. mengungkap jaringan teroris secara tuntas;

i. pembebasan sandra;

j. pembekuan asset organisasi teroris dan kelompok yang berkaitan dengan terorisme;

k. pelaksanaan undang-undang pencucian uang secara konsisten;

1. penelusuran aliran dana jaringan teroris dengan mengeyampingkan rahasia bank.

Langkah-langkah sebagaimana tersebut di atas pada prinsipnya dilakukan untuk melindungi hak asasi tersangka dan korban, serta memberikan batas-batas yang jelas tentang tindakan yang dapat dilakukan dan tindakan yang tidak boleh dilakukan oleh aparat

Pelaksanaan penegakan hukum berdasarkan UU No. 8 Tahun 1981 (KUHAP) secara imperatif merupakan suatu usaha yang sistematis dan saling melakukan keterpaduan. Terpadu yang dimaksud dalam penegakan hukum pidana ini merupakan penegasan sistem peradilan pidana yang berarti terdapat suatu keterpaduan pendapat, sikap dan langkah terhadap pencegahan serta pemberantasan kejahatan dalam suatu masyarakat. Masing-masing komponen dalam proses peradilan pidana tidak mungkin dapat melakukan pemberantasan terhadap kejahatan yang terjadi kalau saja hanya mengutamakan kepentingan bagi lembaganya sendiri-sendiri tanpa melakukan koordinasi dan melihat kepentingan terbesar dari suatu sistem. Masing-masing komponen merupakan sub-sistem dalam keseluruhan sistem peradilan pidana. 
Dalam sistem peradilan pidana terpadu, bekerjanya sub-sistem harus terintegrasi (terpadu) dengan sub sistem lainnya, harus ada persamaan persepsi dalam memahami persoalan hukum pidana yang terjadi dengan tetap melihat tujuan pokok adanya sistem peradilan pidana. Apabila sejak awal terjadi ketidakterpaduan, sudah dapat dipastikan bekerjanya sistem sebagai sarana hukum pidana mengalami kekagagalan, yang pada gilirannya kepercayaan masyarakat terhadap sub-sistem tersebut secara keseluruhan akan hilang.

Mengingat kompleksnya beban tugas penyidik Polri, maka perlu ilmu lain sebagai alat bantu dalam rangka mencapai keberhasilannya. Ilmu sebagai alat bantu yang dimaksud adalah ilmu manajemen penyidikan. Kebutuhan akan ilmu manajemen penyidikan untuk mendukung keberhasilan penyidik Polri dalam melaksanakan tugas penyidikan, secara konseptual memang sudah ada dan dikembangkan di lingkungan Polri, tetapi dalam praktik adakalanya terkendala karena spesifikasi tindak pidana yang sedang disidik, seperti tindak pidana pencemaran lingkungan hidup, korupsi, terorisme, dan lain-lain.

Manajemen penyidikan ini perlu dikuasai oleh setiap personil Densus 88 AT Polri, karena:

a. masa penahanan yang dilakukan penyidik adalah terbatas dan dibatasi;

b. banyaknya kasus atau perkara yang diterima oleh Polri dan tidak bisa ditolak;

c. sumber daya manusia Polri yang masih rendah dan tidak konsisten;

d. anggaran yang dibutuhkan dan dikeluarkan cukup besar dalam proses penyidikan; dan

e. sarana dan prasarana yang dimiliki Polri terbatas.

Ketentuan batas waktu penahanan yang diatur dalam KUHAP berbeda dengan Perpu No. 1 Tahun 2002, karena masa penahan tersangka teroris menurut Perpu No. 1 Tahun 2002 adalah lebih lama dibanding dengan KUHAP. Mengingat tindak pidana terorisme cukup sulit pembuktiannya, maka lamanya penahanan harus dipahami dari aspek penegakan hukum. Perpu No. 1 Tahun 2002 sebagai payung hukum tindak pidana terorisme, selain harus mempertahankan paradigma perlindungan hak asasi tersangka, juga harus melindungi hak asasi korban. 
Romli Atmasasmita (2002: 2), mengatakan bahwa pertama yang harus diperhatikan adalah penafsiran ketentuan tersebut dikaitkan dengan maksud dan tujuan ditetapkannya Perpu No. 1 Tahun 2002, yaitu hendak membongkar tuntas jaringan organisasi teroris, baik di dalam negeri maupun yang berkaitan dengan organisasi teroris internasional dan penafsiran atas ketentuan tersebut jangan hanya dilihat dari aspek pelanggaran hak asasi manusia semata-mata (negativethinking) melainkan juga harus dilihat dari sisi berpikir positif (positive-thinking), karena masalah kegiatan terorisme dan pembuktiannya tidak mudah, apalagi menemukan aktor utamanya maka lamanya waktu penangkapan dan penahanan sangat menentukan juga keberhasilan usaha pembongkaran kasus tersebut. Perpanjangan masa penangkapan dan penahanan dalam Perpu tersebut tidaklah mutatis mutandis merupakan pelanggaran hak asasi manusia, karena justru dengan cara itu penyidik dapat bertindak teliti dan hati-hati dalam pengumpulan buktibukti yang dapat membuka seluruh jaringan teroris dan aktor utama yang berada di balik tragedi terorisme tersebut.

Perpu No. 1 Tahun 2002 memperkenalkan lembaga baru yang memuat ketentuan khusus tentang perlindungan terhadap hak asasi tersangka/terdakwa yang disebut "safe guarding rules". Ketentuan tersebut antara lain memperkenalkan lembaga hukum baru dalam hukum acara pidana yang disebut dengan "hearing" dan berfungsi sebagai lembaga yang melakukan "legal audit" terhadap seluruh dokumen atau laporan intelijen yang disampaikan oleh penyelidik untuk menetapkan diteruskan atau tidaknya suatu penyidikan atas dugaan adanya tindakan terorisme. Guna melindungi hak asasi tersangka diperlukan kehatihatian, tetapi terlalu hati-hati juga akan mengakibatkan pelaku tindak pidana terorisme yang sesungguhnya lepas dari jeratan hukum. Oleh sebab itu, dalam proses pemeriksaan tersangka, perlu juga diperhatikan kemungkinan terjadinya rekayasa yang dilakukan oleh pihak-pihak yang terkait baik penyidik, advokat maupun tersangka dalam pemeriksaan penyidikan.

Berdasarkan Pasal 1 butir 13 UU No. 2 Tahun 2002 disebutkan bahwa penyidikan adalah serangkaian tindakan penyidik dalam hal dan menurut cara yang diatur dalam undang-undang untuk mencari serta mengumpulkan bukti yang 
dengan bukti itu membuat terang tentang tindak pidana yang terjadi dan guna menemukan tersangkanya. Dengan demikian, pada hakekatnya fungsi penyidikan adalah untuk membuat jelas suatu tindakan/perbuatan, sehingga dapat disimpulkan bahwa perbuatan tersebut memang telah memenuhi unsur-unsur untuk disebut sebagai tindak pidana dan membuat jelas bahwa orang yang melakukan perbuatan tersebut dapat disangkakan telah melakukan tindak pidana sesuai alat bukti yang dikumpulkan.

Berbicara mengenai penyidikan tindak pidana pada umumnya, maka proses penyidikannya dilaksanakan berdasarkan aturan yang telah ditetapkan dalam KUHAP, tetapi khusus terhadap tindak pidana terorisme, selain mengacu pada KUHAP, ketentuan mengenai penyidikan yang juga dijadikan sebagai pedoman adalah Perpu No. 1 Tahun 2002 sebagaimana yang telah ditetapkan menjadi undang-undang berdasarkan UU No. 15 Tahun 2003. Hal ini disebutkan dalam Pasal 25 Perpu No. 1 Tahun 2002, bahwa penyidikan, penuntutan dan pemeriksaan di sidang pengadilan dalam perkara tindak pidana terorisme, dilakukan berdasarkan hukum acara yang berlaku, kecuali ditentukan lain dalam Peraturan Pemerintah Pengganti Undang-undang ini. Selanjutnya disebutkan pula bahwa selama proses penyidikan, tersangka dapat ditahan oleh penyidik dalam waktu paling lama 4 (empat) bulan.

Penyidikan terhadap tindak pidana terorisme dapat dimulai jika telah ada bukti permulaan cukup yang dapat diperoleh dari setiap laporan intelijen, tetapi berdasarkan Pasal 26 Perpu No. 1 Tahun 2002, disebutkan bahwa penetapan sudah dapat atau diperoleh bukti permulaan yang cukup harus dilakukan proses pemeriksaan oleh Ketua atau Wakil Ketua Pengadilan Negeri yang dilaksanakan secara tertutup dalam waktu paling lama 3 (tiga), sedangkan dalam Pasal 28 disebutkan bahwa penyidik dapat melakukan penangkapan terhadap setiap orang yang diduga keras melakukan tindak pidana terorisme berdasarkan bukti permulaan yang cukup dalam waktu paling lama 7 x 24 (tujuh kali dua puluh empat) jam. Alat bukti pemeriksaan tindak pidana terorisme sebagaimana yang disebutkan pada Pasal 27 Perpu No. 1 Tahun 2002, terdiri dari: 
a. alat bukti sebagaimana dimaksud dalam Hukum Acara Pidana;

b. alat bukti lain berupa informasi yang diucapkan, dikirimkan, diterima, atau disimpan secara elektronik dengan alat optik atau yang serupa dengan itu;

c. data, rekaman atau informasi yang dapat dilihat, dibaca, dan/atau didengar, yang dapat dikeluarkan dengan atau tanpa bantuan suatu sarana, baik yang tertuang di atas kertas, benda fisik apapun selain kertas, atau yang terekam secara elektronik, termasuk tetapi tidak terbatas pada:

1) tulisan, suara, atau gambar;

2) peta, rancangan, foto, atau sejenisnya;

3) huruf, tanda, angka, simbol, atau perforasi yang memiliki makna atau dapat dipahami oleh orang yang mampu membaca atau memahaminya.

Kekayaan pelaku tindak pidana terorisme dapat diblokir berdasarkan Pasal 29 Perpu No. 1 Tahun 2002, yang menentukan bahwa penyidik, penuntut umum, atau hakim berwenang memerintahkan kepada bank dan lembaga jasa keuangan untuk melakukan pemblokiran terhadap harta kekayaan setiap orang yang diketahui atau patut diduga merupakan hasil tindak pidana terorisme dan/atau tindak pidana yang berkaitan dengan terorisme. Perintah pemblokiran tersebut harus dilakukan secara tertulis dengan menyebutkan secara jelas mengenai:

a. nama dan jabatan penyidik, penuntut umum, atau hakim;

b. identitas setiap orang yang telah dilaporkan oleh bank dan lembaga jasa keuangan kepada penyidik, tersangka, atau terdakwa;

c. alasan pemblokiran;

d. tindak pidana yang disangkakan atau didakwakan; dan

e. tempat harta kekayaan berada.

Bank dan lembaga jasa keuangan setelah menerima perintah penyidik, penuntut umum, atau hakim, wajib melaksanakan pemblokiran sesaat setelah surat perintah pemblokiran diterima dan wajib menyerahkan berita acara pelaksanaan pemblokiran kepada penyidik, penuntut umum atau hakim paling lambat 1 (satu) hari kerja terhitung sejak tanggal pelaksanaan pemblokiran. Apabila ketentuan ini tidak dilaksanakan, maka Bank dan lembaga jasa keuangan dimaksud dapat 
dijatuhi sanksi administratif sesuai dengan ketentuan peraturan perundangundangan yang berlaku.

Berdasarkan Pasal 30 Perpu No. 1 Tahun 2002, ditentukan bahwa untuk kepentingan pemeriksaan dalam perkara tindak pidana terorisme, maka penyidik, penuntut umum atau hakim, berwenang untuk meminta keterangan dari bank dan lembaga jasa keuangan mengenai harta kekayaan setiap orang yang diketahui atau patut diduga melakukan tindak pidana terorisme dan dalam hal ini tidak berlaku ketentuan undang-undang yang mengatur tentang rahasia bank dan kerahasiaan transaksi keuangan lainnya. Permintaan keterangan harus diajukan secara tertulis dengan menyebutkan secara jelas mengenai:

a. nama dan jabatan penyidik, penuntut umum, atau hakim;

b. identitas setiap orang yang diketahui atau patut diduga melakukan tindak pidana terorisme;

c. tindak pidana yang disangkakan atau didakwakan; dan

d. tempat harta kekayaan berada.

Surat permintaan untuk memperoleh keterangan tersebut harus ditandatangani oleh:

a. Kepala Kepolisian Daerah atau pejabat yang setingkat pada tingkat Pusat dalam hal permintaan diajukan oleh penyidik;

b. Kepala Kejaksaan Tinggi dalam hal permintaan diajukan oleh penuntut umum;

c. Hakim Ketua Majelis yang memeriksa perkara yang bersangkutan.

Sesuai ketentuan Pasal 31 Perpu No. 1 Tahun 2002, berdasarkan bukti permulaan yang cukup maka penyidik berhak untuk:

a. membuka, memeriksa, dan menyita surat dan kiriman melalui pos atau jasa pengiriman lainnya yang mempunyai hubungan dengan perkara tindak pidana terorisme yang sedang diperiksa;

b. menyadap pembicaraan melalui telepon atau alat komunikasi lain yang diduga digunakan untuk mempersiapkan, merencanakan, dan melakukan tindak pidana terorisme. 
Tindakan penyadapan hanya dapat dilakukan atas perintah Ketua Pengadilan Negeri untuk jangka waktu paling lama 1 (satu) tahun dan harus dilaporkan atau dipertanggungjawabkan kepada atasan penyidik.

Terkait dengan upaya untuk memperoleh keterangan dari saksi dan orang lain yang bersangkutan dengan tindak pidana terorisme, maka berdasarkan Pasal 32 Perpu No. 1 Tahun 2002, harus dilakukan secara bebas dan tanpa tekanan. Orang-orang tersebut harus dirahasiakan nama atau alamat atau hal-hal lain yang memberikan kemungkinan dapat diketahuinya identitas, dan kerahasiaan ini diberitahukannya sebelum pemeriksaan.

Menurut ketentuan Pasal 1 angka 1 KUHAP ditentukan bahwa: penyidik adalah Pejabat Polisi Negara Republik Indonesia atau Pejabat Pegawai Negeri Sipil tertentu yang diberi wewenang khusus oleh Undang-undang untuk melakukan penyidikan, sedangkan dalam Pasal 1 angka 2 KUHAP ditegaskan bahwa: penyidikan adalah serangkaian tindakan penyidik dalam hal dan menurut cara yang diatur dalam undang-undang ini untuk mencari serta mengumpulkan bukti yang dengan bukti itu membuat terang tindak pidana yang terjadi dan guna menemukan tersangkanya. Rumusan ini memberikan penekanan bahwa tugas utama polisi ialah:

a. mencari dan mengumpulkan bukti yang dengan bukti-bukti tersebut membuat terang tindak pidana yang terjadi; dan

b. menemukan tersangka.

Dalam melaksanakan tugas penyidikan terhadap tindak pidana terorisme kelompok radikal, Penyidik pada Densus 88 AT Polri tentunya mempunyai kewenangan seperti yang diatur dalam Pasal 7 KUHAP, yaitu:

a. menerima laporan atau pengaduan tentang adanya tindak pidana;

b. melakukan tindakan pertama pada saat di tempat kejadian;

c. menyuruh berhenti dan memeriksa tanda pengenal diri seseorang tersangka;

d. melakukan penangkapan, penahanan, penggeledahan dan penyitaan;

e. melakukan pemeriksaan dan penyitaan surat;

f. mengambil sidik jari dan memotret seseorang;

g. memangil orang untuk didengar dan diperiksa sebagai tersangka atau saksi; 
h. mendatangkan seorang ahli yang diperlukan dalam hubungan dengan pemeriksaan perkara;

i. mengadakan penghentian penyidikan; dan

j. mengadakan tindakan lain menurut hukum yang bertanggungjawab

Mengingat kekhususan tindak pidana terorisme merupakan tindak pidana yang luar biasa, maka kewenangan untuk melaksanakan penyidikan tindak pidana terorisme kelompok radikal berada pada Penyidik Subden Investigasi Densus 88 AT Polri dan setelah berlakunya Peraturan Kapolri No. 21 Tahun 2010, maka Subden Investigasi berganti nama menjadi Bidang Investigasi Densus 88 AT Polri. Sesuai dengan Peraturan Kapolri No. 21 Tahun 2010, maka Bidang Investigasi Densus 88 AT Polri bertugas melaksanakan penyidikan terhadap tindak pidana terorisme sesuai peraturan perundang-undangan.

Selanjutnya dalam Peraturan Kapolri No. 21 Tahun 2010 ditentukan pula bahwa Bidang Investigasi dalam melaksanakan tugasnya menyelenggarakan fungsi:

a. penyidikan tindak pidana terorisme mulai dari tahap pembuatan laporan polisi sampai dengan tahap pelimpahan berkas perkara, tersangka dan barang bukti ke Penuntut Umum;

b. pencatatan setiap kegiatan penyidikan yang dilaksanakan dalam administrasi penyidikan tindak pidana terorisme;

c. pelaksanaan koordinasi dan kerjasama dengan unsur bantuan teknis labfor, identifikasi, penjinak bom, kedokteran forensik dalam rangka pengolahan TKP dan pembuktian ilmiah;

d. pelaksanaan koordinasi dengan aparat penegak hukum lainnya yang tergabung dalam CJS (Criminal Justice Sistem);

e. pelaksanaan pembinaan fungsi, pengawasan dan pengendalian penyidikan tindak pidana terorisme yang dilakukan oleh Satgas Wilayah;

f. pelaksanaan gelar perkara bersama instansi terkait;

g. pelaksanaan kegiatan lain yang berkaitan dengan penyidikan tindak pidana terorisme; dan 
h. pengawasan terhadap aliran dana dan transaksi keuangan yang digunakan untuk kegiatan terorisme;

Atas dasar pengetahuan dan keterampilannya, serta kewenangan dan fungsi Bidang Investigasi Densus 88 AT Polri ini, maka aparat Penyidik pada Bidang Investigasi Densus 88 AT Polri telah dapat mengungkap kasus tindak pidana terorisme dengan kelompok radikal. Pengungkapan kasus ini tentunya dilaksanakan sesuai dengan kewenangan yang diatur dalam Pasal 7 KUHP, antara lain dengan melaksanakan pemeriksaan di tempat kejadian perkara (TKP), melakukan penangkapan, penahanan, penggeledahan dan penyitaan, serta melakukan pemeriksaan terhadap saksi-saksi.

Salah satu kunci keberhasilan aparat Penyidik pada Densus 88 AT Polri untuk mengungkap kasus tindak pidana terorisme kelompok radikal, selain karena personil Densus 88 AT Polri merupakan aparat kepolisian yang sudah terlatih untuk mengungkap tindak pidana terorisme, juga karena berdasarkan hasil pemeriksaan di TKP, ditemukan sejumlah barang bukti berupa peralatan dan bahan-bahan pembuat bom, senjata api dan yang tidak kalah pentingnya adalah berdasarkan keterangan-keterangan yang diperoleh dari para saksi yang diperiksa penyidik Densus 88 AT Polri.

Dalam setiap proses penyidikan tindak pidana (termasuk tindak pidana terorisme), pemeriksaan di TKP merupakan tindakan penting yang harus dilakukan oleh penyidik, terutama untuk mencari dan mengumpulkan barang bukti. Hal ini sesuai dengan penjelasan Chairuddin Ismail seperti yang diuraikan pada Bab II, bahwa hakekat penyidikan suatu tindak pidana (crime investigation) adalah pembuktian yang diperoleh melalui suatu proses yang menggunakan segitiga pembuktian sebagai pisau analisis. Segitiga pembuktian itu adalah: tempat kejadian perkara (crime scene), barang bukti (clue evidence), pelaku (suspect) dan saksi (witness). Tempat kejadian perkara (TKP) menjadi titik sentral segitiga tersebut karena tempat kejadian perkara tidak lain adalah babak terakhir dari suatu peristiwa kejahatan, yang di dalamnya terdapat banyak petunjuk atau bukti. 


\section{Simpulan dan Saran}

\section{Simpulan}

Sesuai dengan temuan penelitian yang diperoleh, dapat diketahui bahwa faktor internal yang mempengaruhi pengungkapan tindak pidana terorisme yang dilakukan kelompok radikal adalah dari faktor aparat penegak hukumnya (personil Densus 88 AT Polri). Dari sisi aparat penegak hukumnya, ternyata personil Densus 88 AT Polri yang bertugas melakukan penyelidikan dan penyidikan tindak pidana terorisme yang dilakukan kelompok radikal karena anggota (personil) Densus 88 AT Polri yang memang sudah terlatih dan berpengalaman dalam tugasnya, sehingga pengungkapan kasusnya tidak menemui hambatan atau kendala yang signifikan, dan dari hasil penyelidikan yang dilakukan dengan segera tersangka telah dapat ditangkap untuk melaksanakan penyidikannya.

Dari sisi sarana dan prasarana, Densus 88 AT Polri telah dilengkapi dengan peralatan (teknologi) moderen, serta dukungan pendanaan yang cukup memadai. Hal ini tentunya sangat mendukung bagi percepatan perlaksanaan pengungkapan tindak pidana terorisme yang dilakukan kelompok radikal. Adanya dukungan aparat Densus 88 AT Polri yang mempunyai skill (keahlian) memadai, serta dukungan sarana dan prasarana berupa peralatan teknologi moderen, tentunya juga merupakan kunci keberhasilan dalam pengungkapan kasus tindak pidana terorisme. Oleh sebab itu, dukungan seperti ini hendaknya juga tersedia dalam upaya pengungkapan kasus jenis tindak pidana lainnya.

Faktor pengaruh eksternal yang dimaksudkan dalam pengungkapan kasus tindak pidana terorisme yang dilakukan kelompok radikal, terdiri dari faktor substansi hukum, faktor budaya hukum dan faktor masyarakat. Apabila dilihat dari sisi aturan hukum (undang-undang), maka substansi undang-undang yang terkait dengan pelaksanaan penyidikan terorisme, baik yang tertuang dalam Perpu No. 1 Tahun 2001, KUHAP maupun berbagai regulasi (kebijakan) yang dikeluarkan dan berlaku di lingkungan institusi Polri, juga merupakan salah satu faktor pendukung untuk mengungkapkan kasus tindak pidana terorisme yang dilakukan kelompok radikal. 
Dilihat dari faktor budaya hukum, maka hal ini lebih terkait dengan pemahaman masyarakat terhadap gerakan radikal yang dapat berkembang menjadi kelompok terorisme, maksudnya bahwa sampai saat ini masih ada pemahaman yang dangkal terhadap ajaran Islam, sehingga masih ada sebagian anggota masyarakat yang beranggapan bahwa konsep jihad dengan melakukan aksi teror merupakan ajaran Islam yang memang diperintahkan agama, padahal setiap agama melarang tindakan kekerasan. Konsep jihad tidak boleh dipahami sebagai bentuk perlawanan yang menggunakan kekerasan terhadap siapa saja tanpa sasaran yang jelas.

Dalam hubungannya dengan kasus tindak pidana terorisme yang dilakukan kelompok radikal, dapat dikatakan bahwa dari sisi masyarakat tidak faktor signifikan yang dapat menghambat proses pengungkapannya, karena umumnya masyarakat (kecuali sebagian kecil yang tidak paham) mendukung tugas dan peran Densus 88 AT Polri dalam mengatasi masalah terorisme di Indonesia.

\section{Saran}

Mengingat bahwa masih ada pemahaman sebagian anggota masyarakat yang beranggapan bahwa konsep jihad dengan melakukan aksi teror merupakan ajaran Islam yang memang diperintahkan agama, maka pemerintah dan para ulama hendaknya tetap memberikan pemahaman kepada masyarakat bahwa tindakan terorisme tidak dibenarkan dalam ajaran setiap agama. 


\section{DAFTAR PUSTAKA}

Bagir Manan dalam Sholeh So'an. 2004. Moral Penegak Hukum di Indonesia dalam Pandangan Islam. Bandung: Agung Ilmu.

Barda Nawawi Arief. 2005. Beberapa Aspek Kebijakan Penegakan dan Pengembangan Hukum Pidana. Edisi Revisi. Bandung: Citra Aditya Bakti.

------. 2002. Masalah Penegakan Hukum dan Kebijakan Penanggulangan Kejahatan. Cetakan Kedua. Bandung: Citra Aditya Bakti.

-------. 2001. Masalah Penegakan Hukum dan Kebijakan Penanggulangan Kejahatan. Bandung: Citra Aditya Bakti.

-------. 2001. Kebijakan Legislatif dalam Penanggulangan Kejahatan. Bandung: Citra Aditya Bakti.

-------. 1998. Beberapa Aspek Kebijakan dan Pengembangan Hukum Pidana. Bandung: Citra Aditya Bakti.

Chainur Arrasjid. 1999. Suatu Pemikiran tentang Psikologi Kriminil. Kelompok Studi Hukum dan Masyarakat. Medan: Fakultas Hukum-USU.

Parker, Helbert L. 1968. The Limits of The Criminal Sanction. Calofornia: Stanford University Press.

Henny Nuraeny. 2011. Tindak Pidana Perdagangan Orang, Kebijakan Hukum Pidana dan Pencegahannya. Jakarta: Sinar Grafika.

Kartini Kartono. 2003. Patologi Sosial. Jilid 1. Jakarta: RajaGrafindo Persada.

Mardjono Reksodiputro. 1994. "Hak Asasi Manusia dalam Sistem Peradilan Pidana”. dalam Kumpulan Karangan Buku Ketiga. Jakarta: Pusat Pelayanan Keadilan dan Pengabdian Hukum Universitas Indonesia.

Nyoman Serikat Putrajaya. 2005. Kapita Selekta Hukum Pidana. Semarang: Badan Penerbit UNDIP.

Roeslan Saleh. 1983. Hukum Pidana sebagai Konfrontasi Manusia dan Manusia. Jakarta: Ghalia Indonesia.

Romli Atmasasmita. 2002. Masalah Pengaturan Terorisme dan Perspektif Indonesia. Cetakan Pertama. Jakarta: Percetakan Negara RI.

Simanjuntak, B. 1997. Pengantar Kriminologi dan Patologi Sosial. Bandung: Tarsito.

Soerjono Soekanto. 2004. Faktor Faktor yang Mempengaruhi Penegakan Hukum. Cetakan Kelima.Jakarta: RajaGrafindo Persada.

1981. Kriminologi Suatu Pengantar. Jakarta: Ghalia Indonesia. 
Sudikno Mertokusumo. 1988. Mengenal Hukum (Suatu Pengantar). Yogyakarta: Liberty.

\section{Karya Ilmiah:}

Arsyad Mbai. 2003. "Perlindungan Kedaulatan Wilayah Negara, Hak Asasi Warga Negara dan Tersangka/Terdakwa dalam Kegiatan Tindak Pidana Terorisme". Makalah. disampaikan pada Seminar tentang Penegakan Hukum terhadap Terorisme. Bandung: Kerjasama Badan Pembinaan Hukum Nasional Departemen Kehakiman dan HAM-RI dengan Fakultas Hukum Universitas Padjadjaran. 13-14 Oktober.

\section{Internet:}

Frans H. Winarta, http://www.sinarharapan.co.id.html, diakses pada tanggal 20 Januari 2013. 


\section{BIODATA PENULIS}

$\begin{array}{lll}\text { Nama } & : \text { Ahmad Yasir, S.I.K., S.H. } \\ \text { Pekerjaan } & : \text { Kepolisian Sektor Medan Labuhan } \\ \text { Jabatan } & : \text { Kapolsek } \\ \text { Nomor HP } & : 081386587886 \\ \text { E-mail } & : & \text { yasirahmadi.ptik59@ gmail.com } \\ \text { Alamat Kantor }: & \text { Jl. Titi Pahlawan, Pekan Labuhan, Medan Labuhan, Kota } \\ & & \text { Medan, Sumatera Utara }\end{array}$

